Research Article

\title{
Self-Medication Practices among a Sample of University Students Attending College of Science in Diyala Province
}

\author{
Aqeel Abbas Noaman', Mohammed Ali Hussein $^{2}$, Sarmad Qassim Mohammed ${ }^{3}$ \\ 1,3 Technical Institute/ Baquba, Middle Technical University (MTU), Iraq. \\ ${ }^{2} \mathrm{Al}-M u q d a d$ College for Education, University of Diyala, Iraq. \\ DOI: https://doi.org/10.24321/2394.6539.201907
}

I $\quad \mathbf{N} \quad \mathbf{F} \quad \mathbf{O}$

\section{Corresponding Author:}

Aqeel Abbas Noaman, Technical Institute/ Baquba, Middle Technical University (MTU), Iraq. E-mail Id:

aqeeltech.mtu@mtu.edu.iq

Orcid Id:

https://orcid.org/0000-0002-8432-6504

How to cite this article:

Noaman AA, Hussein MA, Mohammed SQ. Self-Medication Practices among a Sample of University Students Attending College of Science in Diyala Province. J Adv Res Med Sci Tech 2019; 6(3\&4): 13-18.

Date of Submission: 2020-02-01

Date of Acceptance: 2020-02-19

\section{$\begin{array}{lllllllllll}\mathbf{A} & \mathbf{B} & \mathbf{S} & \mathbf{T} & \mathbf{R} & \mathbf{A} & \mathbf{C} & \mathbf{T}\end{array}$}

Background: Self-medication is the use of drugs and painkillers by many people with therapeutic or preventive intent without prior professional advice or prescribed by a physician, including adults to treat their selfrecognized diseases and symptoms.

Objectives: Determine the rate of self-medication practice among university students and determine the most common area to be selfmedicated and the most common drug group for self-medication.

Subjects and Methods: An analytical cross-sectional study of a random sample of students attending two branches of college of science (biology and chemistry) from the period of 10th December 2018 to $15^{\text {th }}$ April 2019 through purposive sampling technique to collect responses from students using structured questionnaire which was divided into many sections including demographic details of research participants, history of taking medication to treat a health problem without a prescription at the last month, the reasons of self-medication practice. Sample size was 220 university students. All data were entered on Microsoft Excel 2010, and managed and analyzed on SPSS version 19. The means and standard deviations were calculated and both t-test and chi-square tests were used to identify the associations between variables. The confidence level was set at $95 \%$, and the $p$ value of less than 0.05 was the limit value of significance.

Result: The rate of practicing self-medication was significantly higher among studied university students and it accounted for (64.1\%). And it was significantly higher in females (62.4\%) than males (37.6\%). Most of the self-medications (59.6\%) were practiced for the pains originating from head and neck. The vast majority of students $(80.9 \%)$ significantly were using analgesics and antipyretic, and most of them $(71.6 \%)$ were practicing it at any time during the year.

Conclusion: The study concluded that the rate of self-medication among university students was at the high level, the self-medication was practiced anytime during the year and the use of analgesics was significantly dominant among other drug groups.

Keywords: Self-medication, Analgesics, University Students, Drug Groups, Chemistry, Biology 


\section{Introduction}

Self-medication is the use of drugs and painkillers by many people with therapeutic or preventive intent without prior professional advice or prescribed by a physician. ${ }^{1}$ Selfmedication includes the use of therapeutic products by people, including adults to treat self-recognized diseases/ indicators. It also indicates the intermittent/ continuous use of the medication prescribed by the physician for permanent or recurrent illnesses/ health condition. ${ }^{2}$ It is really practiced around the world in a wide range of people including university students, especially developing countries as many medications including common drugs and analgesics are taken by these students without a prescription and any irrational use of these medications can affect the general condition of the students. ${ }^{1}$

Today, self-medication is one of the biggest social and economic problems affecting public health in many countries such as Iraq, and this occurs through the consumption of analgesics as non-steroidal anti-inflammatory agents or commonly used medications such as antibiotics and vitamins; taking these medications without a prescription directly by the doctor can expose the users to future health problems such as gastric ulcer. ${ }^{3}$ Analgesics, antibiotics and cough syrup are the most frequently used agents for self-medication in various groups including university students, and the frequency of self-medication arises from a number of factors, including ready access to these drugs, overlapping social, economic and environmental factors as well as demographic and epidemiological factors of the population, with differences in lifestyles and individual behaviors in their daily life, which are based on the availability and accessibility of medical products. ${ }^{4}$

There is great concern about the consumption of medications, since the majority of side effects are often more serious than the original disease itself. In addition, the ability of these drugs to reduce symptoms and then creates a mask that deceives the consumer in a rapid response to alleviate the pain, thereafter worsens his/her health. ${ }^{5}$ It believed that the reason for the repeated selfmanagement of medicines is to achieve the desired effects, since the World Medical Association (WMA) has developed a statement to guide patients, doctors, pharmacists and medical care providers about any type of medication, and defeat management, dosage and number of times, can be used safely and in a proper useful way. ${ }^{6}$ Several studies from the Middle East region, including Iraq and other Arab countries, revealed the high prevalence of self-medication in several universities, where students in those countries used analgesics, herbs, often vitamins and antibiotics, and rarely use opium and sedatives. ${ }^{7}$ In the European countries, there are higher rates of self-medication use in the United Kingdom and Germany, while the regions of Croatia and
Greece are the lowest in prevalence, these rates vary by country. ${ }^{7}$

\section{Objectives}

Determine the rate of self-medication practice among university students and determine the most common area to be self-medicated and the most common drug group for self-medication.

\section{Subjects and Methods}

An analytical cross-sectional study of a random sample of students attending college of science, including the two scientific branches (Biology and Chemistry) after the approval of the University from the period of $10^{\text {th }}$ December 2018 to $15^{\text {th }}$ April 2019 through purposive sampling technique to collect responses from students using structured questionnaire was done; this questionnaire was distributed to students at rest periods after the lecture being completed and it was either taken from the student after 10 minutes or they were allowed to take questionnaires to their homes and return them later. This questionnaire was adapted from various similar studies taken from previous articles, and it was divided into many sections including demographic details of research participants, taking history of medication to treat a health problem without a prescription during the previous month. The questionnaire was tested on a small sample of students using pilot study to ensure easy reading of the information to answer them properly. The distribution of questionnaire for the students was done on the basis of volunteering with an informed consent. Sample size was 220 university students. The sample size taken was small because the students included in the study at the Faculty of Science (Department of Biology and Chemistry) did not exceed 650 university students and for all levels of study. All data were entered on Microsoft Excel 2010, and managed and analyzed on SPSS version 19. The means and standard deviations were calculated for continuous and discrete data respectively. Then, both t-test and chi-square tests were used to identify the associations between variables. The confidence level was set at $95 \%$, and the level of less than 0.05 was the limited value of significance.

\section{Result}

In Table 1, the total rate of practicing self-medication was significantly higher among university students and it accounted for (64.1\%). It was found that the mean age was almost equal for students taking medications and who did not take them without a prescription in males $(20.12 \pm 1.37)$ years and females $(20.21 \pm 1.63)$ years respectively without finding a statistical difference. The results of the study show that the percentage of students who reported the use of self-medication was significantly higher in females (62.4\%) than males (37.6\%) as shown in Table 1. 
Table I.Self-medication users and non-users according to prevalence, mean age and gender

\begin{tabular}{|c|c|c|c|c|c|}
\hline Characteristics & \multicolumn{4}{|c|}{ Self-medication practice } & Statistics \\
\hline \multirow{3}{*}{ Total Prevalence } & \multicolumn{2}{|c|}{ Users } & \multicolumn{2}{|c|}{ Non-users } & \multirow{3}{*}{$\begin{array}{l}\text { Chi-square }=17.473 \\
p \text {-value }=0.000(\mathrm{HS})\end{array}$} \\
\hline & No. & $\%$ & No. & $\%$ & \\
\hline & 141 & 64.1 & 79 & 35.9 & \\
\hline \multirow{3}{*}{ Age/Mean } & \multicolumn{2}{|c|}{ Users } & \multicolumn{2}{|c|}{ Non-users } & \multirow{3}{*}{$\mathrm{t}$-test $=0.21$} \\
\hline & \multicolumn{2}{|c|}{$($ Mean $\pm S D)$} & \multicolumn{2}{|c|}{ 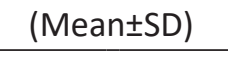 } & \\
\hline & \multicolumn{2}{|c|}{$20.16 \pm 1.411$} & \multicolumn{2}{|c|}{$20.15 \pm 1.341$} & \\
\hline \multirow{2}{*}{ Gender } & \multicolumn{2}{|c|}{ Users } & \multicolumn{2}{|c|}{ Non-users } & \multirow{5}{*}{$\begin{array}{c}\text { Chi-square }=7.693 \\
p \text {-value }=0.004(H S)\end{array}$} \\
\hline & No. & $\%$ & No. & $\%$ & \\
\hline Males & 53 & 37.6 & 45 & 57 & \\
\hline Females & 88 & 62.4 & 34 & 43 & \\
\hline Total & 141 & 100 & 79 & 100 & \\
\hline
\end{tabular}

In Table 2, it was found that the highest percentage of self-medication users (59.6\%) was for the purpose of relieving the head and neck pain with a high statistical difference, while the lowest percentage of them $(7.8 \%)$ was to relieve the tooth pains.

Table 2.Most commonly affected region selfmedicated by students

\begin{tabular}{|c|c|c|c|}
\hline $\begin{array}{l}\text { Most commonly } \\
\text { affected regions self- } \\
\text { medicated by students }\end{array}$ & No. & $\%$ & Statistics \\
\hline Joints and Muscles & 18 & 12.8 & \multirow{5}{*}{$\begin{array}{c}\text { Chi-square }= \\
94.035 \\
\text { p-value }=0.000 \\
\text { (HS) }\end{array}$} \\
\hline Head and Neck & 84 & 59.6 & \\
\hline Teeth & 11 & 7.8 & \\
\hline Abdominal Cavity & 18 & 19.9 & \\
\hline Total & 141 & 100 & \\
\hline
\end{tabular}

The vast majority of students (80.9\%), as shown in table (3), was using analgesics and antipyretic as a self-medication. While the minority ( $8.5 \%)$ was using tonics and vitamins. A high statistical correlation was found in the self-medication with analgesics and antipyretic among university students.

Table 3.Most common drug groups used for self-medication

\begin{tabular}{|c|c|c|c|}
\hline $\begin{array}{l}\text { Most common drug } \\
\text { groups used for self- } \\
\text { medication }\end{array}$ & No. & $\%$ & Statistics \\
\hline Tonics and Vitamins & 12 & 8.5 & \multirow{4}{*}{$\begin{array}{c}\text { Chi-square= } \\
234.972 \\
\text { p-value }=0.000 \\
\text { (HS) }\end{array}$} \\
\hline $\begin{array}{c}\text { Analgesics and } \\
\text { Antipyretics }\end{array}$ & 114 & 80.9 & \\
\hline Antibiotics & 15 & 10.7 & \\
\hline Total & 141 & 100 & \\
\hline
\end{tabular}

Table 4, shows that most students in the sample study (71.6\%) self-medicated at any time of the year; while the minority $(5.7 \%)$ self-medicated once a year.

Table 4.Frequency of use of self-medication during the year

\begin{tabular}{|c|c|c|c|}
\hline $\begin{array}{l}\text { Frequency of use of self- } \\
\text { medication }\end{array}$ & No. & $\%$ & Statistics \\
\hline Once a year & 8 & 5.7 & \multirow{5}{*}{$\begin{array}{c}\text { Chi-square= } \\
164.787 \\
\text { p-value }=0.000 \\
\text { (HS) }\end{array}$} \\
\hline Two to three times a year & 15 & 10.6 & \\
\hline Several times per year & 17 & 12.1 & \\
\hline Anytime during the year & 101 & 71.6 & \\
\hline Total & 141 & 100 & \\
\hline
\end{tabular}

\section{Discussion}

It is well known that self-medication is prevalent throughout the world and approximately $60 \%$ to $80 \%$ of health problems in developing countries result from people resorting to self-medication. ${ }^{8}$ In this study, the estimated rate of selfmedication practice was found to be 64.1 percent. This was similar to Iraqi ${ }^{6}$ and Turkish study. ${ }^{9}$ It was almost consistent with another study conducted in Karnataka, ${ }^{8}$ and it was lower than what was found in many other investigations like Bangladesh, ${ }^{10}$ Nigeria $^{11}$ and Egypt. ${ }^{12}$ These variations in different countries may be due to differences in the duration of self-medication practices, the demographic and social characteristics of the target population, the size of the sample, and the level of their knowledge of self-medication. ${ }^{13}$

It was found that the mean age for both genders was almost equal for students who self-medicated and who didn't; this is important to correctly interpret that self-medication is a global phenomenon prevalent in every age group, although its range varies across regions and people. ${ }^{14}$ 
Significantly, females reported using the drugs over the counter more than the males, and they accounted for $62.4 \%$. This was close to Al Shawi et al. in the city of Anbar, Iraq. ${ }^{15}$ This study indicated that the head and neck areas have significantly reached the highest rate that makes university student use self-medication. The cause might be that headaches are common among college students because nearly $47 \%$ of the world's population complains about some types of headaches and roughly $15 \%$ to $20 \%$ of those with a headache of cervicogenic origin. ${ }^{16}$ This study significantly revealed that most of the students who reported the use of self-medication were females. This finding was consistent with other Arabic studies. , $17,18,19^{-19}$ However, the high rate of self-medication in females may be due to their feeling of fatigue and pain, especially pains of the menstrual cycle, which makes them soon go to using pain relievers and some antibiotics. Significantly, the majority of students $(80.9 \%)$ in the study reported the use of Analgesics as the most common agent for self-medication. These findings were similar to the study of Alshogran et al. in Jordan ${ }^{18}$ and comparable to several other studies conducted on a number of medical students: $76.6 \%$ in $\operatorname{Iran}^{20}$ and two other Saudi studies $72.35 \%{ }^{14}$ and $89.7 \%,{ }^{21}$ respectively. The reason may be that the analgesics are available to get a sense of comfort and quick relief of pain. ${ }^{8}$ Moreover, there is an easy access to medicines, including analgesics from pharmacy owners and drug stores. More than 10 percent of students reported using antibiotics frequently without going to a doctor, while their irrational use increases the risk of bacteria being resistant to antibiotics. ${ }^{22,23}$ This study revealed that nearly three quarters of students were self-medicating at any time during the year. This may be due to the conviction of a person for his or her experience in choosing a medication and a suitable analgesic for his/her health in many cases during one year.

\section{Conclusion}

The study concluded that the rate of self-medication among university students was high and self-medication was practiced anytime and the use of analgesics was ranked first among other drug groups.

\section{Recommendation}

The competent authorities should spread health awareness on the campus of colleges and should put some warning posters regarding the dangers of self-medication while urging students to avoid this phenomenon and to do some seminars regarding all matters related to self-medication.

\section{Conflict of Interest: None}

\section{References}

1. Shah H, Patel R, Nayak S, Patel HR, Sharma D. A questionnaire-based cross-sectional study on self- medication practices among undergraduate medical students of GMERS Medical College, Valsad, Gujarat. International Journal of Medical Science and Public Health 2018; 7(4): 249-254. Available from: https:// www.ijmsph.com/?mno=288019 [Google Scholar].

2. Nagarajaiah BH, Kishore MS, Shashi Kumar NS and Praveen Panchakshari. Prevalence and pattern of self-medication practices among population of three districts of South Karnataka. National Journal of Physiology, Pharmacy and Pharmacology 2016; 6(4): 296-300. Available from: http://www.njppp.com/ fulltext/28-1454339198.pdf [Google Scholar].

3. Arman Latifi, Ramezankhani A, Rezaei Z, Ashtarian H. Prevalence and associated factors of self-medication among the college students in Tehran. Journal of Applied Pharmaceutical Science 2017; 7(7): 128-132. Available from: https://www.researchgate.net/profile/ ehdi_Khezeli/publication/319092582_Prevalence_ and_associated_factors_of_self-medication_among_ the_college_students_in_Tehran/links/5d355a50299bf 1995b3f9eeb/Prevalence-and-associated-factors-ofself-medication-among-the-college-students-in-Tehran. pdf [Google Scholar/ ResearchGate].

4. Osama BA, Mahfouz MS, Masmali BM, Ageeli RA, Majrashi AM, Hakami AN et al. Self-medication practice among undergraduate medical students of a Saudi tertiary institution. Tropical Journal of Pharmaceutical Research 2016; 15(10): 2253-2259. Available from: https://www.ajol.info/index.php/tjpr/article/ view/147813 [Google Scholar].

5. Pereira CM, Alves VF, Gasparetto PF, Carneiro DS, Rocha de CG, Ferreira Valoz FE. Self-medication in health students from two Brazilian universities. RSBO 2012; 9(4): 361-367. Available from: http:// revodonto.bvsalud.org/scielo.php?script $=$ sci_ arttext \&pid=S1984-56852012000400003 [Google Scholar].

6. Ahmed NM, Sulaiman KH. Self-Medication Practice among Patients Attending a sample of Primary Health Care Centers in Erbil City. Journal of Education and Practice 2016; 7(24): 73-79. Available from: https:// eric.ed.gov/?id=EJ1112859 [Google Scholar].

7. Al-Ameri JK and Al-Badri H. Prevalence of selfmedication among university students in Baghdad: A cross-sectional study from Iraq. Eastern Mediterranean Health Journal 2017; 23(2): 87-93. Available from: http://www.emro.who.int/emhj-volume-23-2017/ volume-23-issue-2/prevalence-of-self-medicationamong-university-students-in-baghdad-a-crosssectional-study-from-iraq.html [Google Scholar/ ResearchGate].

8. Shivamurthy Sh, Manchukonda R, Gurappanavar D. Evaluation of analgesic self-medication pattern among 
under-graduate medical students of Adichunchanagiri Institute of Medical Sciences, BG Nagar, Karnataka: a cross-sectional questionnaire-based study. International Journal of Basic \& Clinical Pharmacology 2015; 4(3): 438-441. Available from: https://www.ijbcp.com/index. php/ijbcp/article/view/761 [Google Scholar].

9. Okyay RA and Erdogan AS. Self-medication practices and rational drug use habits among university students: a cross-sectional study from Kahramanmaras, Turkey. PeerJ 2017; 1-14. [PubMed/ Google Scholar].

10. Seam MOR, Bhatta R, Saha BL, Das A, Hossain MM, Uddin SMN et al. Assessing the Perceptions and Practice of Self-Medication among Bangladeshi Undergraduate Pharmacy Students. Pharmacy 2018; 6(6): 1-12. Available from: https://www.mdpi.com/2226-4787 /6/1/6 [PubMed/ Google Scholar].

11. Osemene KP, Lamikanra A. A Study of the Prevalence of Self-Medication Practice among University Students in Southwestern Nigeria. Tropical Journal of Pharmaceutical Research August 2012; 11(4): 683-689. Available from: https://www.ajol.info/index.php/tjpr/ article/view/80589 [Google Scholar].

12. El-Nimr NA, Wahdan IMH, Wahdan AMH, Kotb RE. Self-medication with drugs and complementary and alternative medicines in Alexandria, Egypt: prevalence, patterns and determinants. Eastern Mediterranean Health Journal 2015; 21(4): 256-265. Available from: http://www.emro.who.int/emhj-volume-21-2015/ volume-21-issue-4/self-medication-with-drugsand-complementary-and-alternative-medicinesin-alexandria-egypt-prevalence-patterns-anddeterminants.html [Google Scholar].

13. Araia ZZ, Gebregziabher NK and Mesfun. AB. Selfmedication practice and associated factors among students of Asmara College of Health Sciences, Eritrea: a cross sectional study. Journal of Pharmaceutical Policy and Practice 2019; 12(3): 1-9. Available from: https://joppp.biomedcentral.com/articles/10.1186/ s40545-019-0165-2 [Google Scholar].

14. Albusalih FA, Naqvi AA, Ahmad R, Ahmad N. Prevalence of Self-Medication among Students of Pharmacy and Medicine Colleges of a Public Sector University in Dammam City, Saudi Arabia. Pharmacy 2017; 5(51): 1-13. Available from: https://www.mdpi.com/22264787/5/3/51 [PubMed/ Google Scholar].

15. Al Shawi AF, Ali AF, Enad MM, Salih JA. Self-medication among medical students in Anbar and Fallujah Universities-Iraq. J Fac Med Baghdad 2018; 60(3):156159. Available from: http://iqjmc.uobaghdad.edu.iq/ index.php/19JFacMedBaghdad36/article/view/606 [Google Scholar].

16. Page P. Cervicogenic Headaches: An Evidence-Led Approach To Clinical Management. The International
Journal of Sports Physical Therapy 2011; 6 (3): 254-266. [PubMed/ Google Scholar].

17. Al-Hussaini M and Mustafa S. Self-medication among undergraduate medical students in Kuwait with reference to the role of the pharmacist. Journal of Research in Pharmacy Practice 2014; 3(1): 23-27. [PubMed/ Google Scholar].

18. Alshogran OY, Alzoubi KH, Khabour OF, Shatha F. Patterns of self-medication among medical and nonmedical University students in Jordan. Risk Management and Healthcare Policy 2018; 11: 169-176. [PubMed/ Google Scholar].

19. Shehnaz SI, Khan N, Sreedharan J. Prevalence and practice of self-medication among medical students. Gulf Medical Journal 2013; 2(S2) :S86-S92. Available from: https://pdfs.semanticscholar.org/ 0da8/51cf60323ef2cca36d2a7e1b68dc82440665.pdf [Google Scholar].

20. Sarahroodi Sh, Sawalha A, Mikaili P, Safaeian L. Pattern of Self-Medication with analgesics among Iranian University Students in central Iran. Journal of Family and Community Medicine 2012; 19(2): 125-129. [PubMed/ Google Scholar].

21. AlRaddadi KK, Barakeh RM, AlRefaie SM, AlYahya LS, Adosary MA et al. Determinants of Self-medication among Undergraduate Students at King Saud University: Knowledge, Attitude and Practice. Journal of Health Specialties 2017; 5(2): 95-101. Available from: http:// www.thejhs.org/article.asp?issn=2468-6360;year $=20$ 17; volume $=5$;issue $=2$; spage=95; epage $=101$; aulast $=\mathrm{Al}$ Raddadi [Google Scholar].

22. Abutiheen AAK, Sallum HH and Obaid NA. Misuse of Antibiotics in Al-Hussein Teaching Hospital in Kerbala. Karbala J Med 2017; 10(2): 2732-2739. Available from: https://www.iasj.net/iasj?func=article \&ald=129717 [Google Scholar].

23. Jumaa KM, Hussein SA-R, Jaffer AA, Abdel Alaziz AS, Abdel Latif RA. Antibiotic Prescription Pattern in Surgery Department in Baquba Teaching Hospital. The N Iraqi J Med 2011; 7(2): 33-40. [Google Scholar/ ResearchGare]. 


\section{Questionnaire}

\section{Notes}

1. Participation is voluntary.

2. Before you see the questionnaire and answer the required paragraphs, please read the questions carefully for at least 10 minutes.

3. After completing all the answers please submit the questionnaire to one of the researchers involved in the research.

4. If you are unable to answer during the required period, you can take the questionnaire to your home, answer it and then deliver it the next day.

\section{Required Information}

Provide the appropriate answer for all the questionnaire items please

1. Age: years

2. Gender

a- Males

b- Females

3. Over the past month have you taken over-the-counter medication.

a- Yes

b- No

4. What is the affected region need to be self-medicated by students

a- Joints and Muscles

b- Head and Neck

c- Teeth

d- Abdominal Cavity

5. What is the most commonly drug groups used for self-medication

a- Tonics and Vitamins

b- Analgesics and Antipyretics

c- Antibiotics

6. Frequency of self-medication during the year

a- Once a year

b- Two to three times a year

c- Several times per year

d- Anytime during the year 